Article

\title{
How Does Water Behave? Unstable Milieu and Stable Agencements in Dakar's Flooded Suburbs
}

\author{
Romain Leclercq ${ }^{1,2}$ \\ ${ }^{1}$ Earth Politics Center, University of Paris / Sciences Po, France; romain.leclercq2@gmail.com \\ ${ }^{2}$ Laboratoire Architecture Ville Urbanisme Environnement (LAVUE), France
}

Submitted: 8 April 2021 | Accepted: 2 August 2021 | Published: 11 January 2022

\begin{abstract}
In the suburbs of Dakar, matter as a flux is not a metaphor anymore, but a concrete process of city fluidification, disintegration, or solidification. Indeed, the city has been concerned for more than 30 years by regular floods that were established permanently in some districts. Drawing from an assemblage perspective, this article aims to understand how people deal with untamed waters in flooded neighbourhoods and at the city scale. It also raises questions about how we can capture the processes of production, maintenance, and disintegration of cities by identifying stable forms of assemblages and by comparing them according to the specific action that they support.
\end{abstract}

\section{Keywords}

Accra; agencements; assemblage; Dakar; Djiddah Thiaroye Kao; flooding; untamed waters

Issue

This article is part of the issue "City as Flux: Interrogating the Changing Nature of Urban Change" edited by Aseem Inam (Cardiff University).

(C) 2022 by the author(s); licensee Cogitatio (Lisbon, Portugal). This article is licensed under a Creative Commons Attribution 4.0 International License (CC BY).

\section{Introduction}

In the last 20 years, many researchers have used the notion of "assemblage" to express the fluidity of urban fabric and practices. In a huge body of literature (see, e.g., McFarlane, 2011; McGuirk et al., 2016; Simone, 2010), the notion designates the rhizomatic and fluid nature of the urban, made by heteroclite associations between heterogenic elements and actors, enrolled by different forms of collective actions, and engaging processes of territorialisation and deterritorialisation. Allowing to go beyond the frontier of human and non-human, material and immaterial, and formal and informal to understand how these different elements are actively entangled to "compose" the city, this line of thought has been the target of much criticism for its supposed "naïve objectivism" (Brenner et al., 2011; Scott \& Storper, 2015). For the latter, assemblage thinking would not allow differentiating matter is in urban processes. If the reality is fluid, made by precarious arrangements, how do we know the forces that really orient these arrangements, global capital, or dynamics of "city land nexus"? The aim of this article is not to add another stone to this ongoing debate. By analysing the case study of the Dakar suburbs in Senegal, affected by permanent floods for over 30 years, I will try to understand the different ways that dwellers, local organisations, and NGOs are crafting specific kinds of assemblages to deal with, contain, or orient untamed waters. Seriously considering the criticism towards assemblage thinking, I will nevertheless emphasise what differentiates these assemblages, to understand what they do, their consequences on the city making, and how they are structured and why. We will see that it requires attention on the human-water association and a theoretical addition to the notion of assemblage.

The understanding of dynamics and agencies of the flux of matters is at the core of recent works attempting to reconstitute how cities are made and unmade (Choplin, 2019, in press; Meulemans, 2020). Especially in the time of the Anthropocene, it has become crucial to understand how city dwellers and city makers are building landscapes, arranging elements and entities like concrete, water, or soils (Tsing et al., 2019), but also 
how these elements are transforming urban landscapes. In the Dakar suburbs, my thesis field, this task is crucial since water has already engulfed entire neighbourhoods. Matter as a flux is not a metaphor anymore, but a concrete process of city disappearance, disintegration, or solidification. I will characterise this process by analysing the "behaviours" of water, that is to say, how flooding waters affect neighbourhoods and their inhabitants. We will see that the understanding of how the water behaves within the city and through the lens of affected dwellers and policymakers will allow us to differentiate some circumscribed assemblages of action within the flooded city.

Trying to draw from the sometimes-dizzying thought of Deleuze and Guattari (1975), sociologists recently returned to their original term of "agencement" to discriminate different forms of "composite objects" (Dodier \& Stavrianakis, 2018). For Callon (2017), the use of agencement allows emphasising the active function of assemblages that are no longer resumed to contingent associations of heterogenic elements. To be clear, agencements are assemblages that have a goal: They are an association of different actors and elements that achieve a specific action. In this article, we will try to separate different agencements that involve flooding waters according to their specific action on the city. In doing so, we will see that these different agencements are not equivalents in terms of actors and elements involved, of scales, objectives, and claimed worth (Boltanski \& Thévenot, 2006). They draw different forms, more or less stable, which I will try to name in order to differentiate them and thus begin to understand which one "matters" and how. From now, I will use the term agencement to designate a composite "collective action, strategic, structured and oriented toward the solving of a problem" (Callon, 2017, p. 402).

First, I will try to give an overview of different "behaviours" of flooding waters in the Dakar suburbs. Drawing from these behaviours, we will see that they relate to specific agencements, supported by affected city dwellers and other actors, to protect themselves against the floods, or to "relieve the community." In so doing, we will start to differentiate two types of floodrelated agencements in affected neighbourhoods according to their goal, the actors involved, and the type of water behaviours that they address. Then, we will observe how an alliance of local organisations and NGOs tried to address the floods problem at a municipal scale and then of the entire agglomeration, engaging different types of negotiations and arrangements between actors involved. In the conclusion, I will argue for intermediate objects, here flood-related agencements, to be replaced in the set of constraints and possibilities that frame actions of city dwellers to understand the constant production and disintegration of urban milieus.

This article is based on a multi-sited ethnography (Marcus, 1995) of the floods in the suburbs of Dakar and Accra, conducted between 2015 and 2019, and alternat- ing observational participation, participant observations, and semi-structured interviews (Cefaï, 2010; Tedlock, 1991). My Dakar enquiry focused on a suburban municipality, Djiddah Thiaroye Kao (DTK), following ramifications that also led me from the city courtyard to World Bank or state agencies offices. This corpus consists of 59 semi-structured interviews, almost all of which were recorded and conducted with the above-mentioned actors, members of NGOs, state agencies or the administration, international institutions, residents' organisations, or the municipality of DTK directly concerned with flood management in the Dakar suburbs. These materials only make sense in light of about 400 pages of observation notes and a large number of documents from the grey literature (project documents, diagnostic documents, and communication documents for the various collective action mechanisms observed). In addition, there are about 600 newspaper articles of varying length (sometimes simple sidebars) concerning flooding, urban planning, and rainfall, over a period ranging from 1987 to 2009. Due to time constraints and difficulties in procuring this last material, I have not continued the research after this last date.

\section{Understanding the "Behaviours" of Water}

In some neighbourhoods in the suburbs of Dakar, negotiations with water characterise an entirety of "living" practices (Rose, 2012). Inherited from a long history involving the variations of the Sahelian climate, the largely informal expansion of the city throughout the twentieth century, the dynamics of the water tables, and the dunes on which the city was built, flooding has indeed the particularity of having established there (Leclercq, 2020). Figure 1 presents one of the aspects of this phenomenon. Under the effect of the rising water table under the Dakar suburbs area and the resurgence of rainfall in the late 1980s after a long period of drought, some neighbourhoods have been literally engulfed by water (Figures 1 and 2), forcing their inhabitants to abandon them, and leaving room for brackish water, aquatic plants (typha), and garbage (O. Cissé, 2019; Thiam, 2011).

However, the abandonment of neighbourhoods is only the most extreme form of how water reshapes the city and the living forms. The topography of the area, made up of largely urbanised dunes, and now inhabited former wetlands (niayes), and the gradual and non-homogeneous rise of the water table, under the effect of the return of the rains and the cessation of its pumping by the public authorities at the beginning of the 2000s (Leclercq, 2017), led to a form of "nibbling" of the city by the water. In addition to having settled in certain neighbourhoods, the waters progressed from year to year, engulfing more and more houses until the late 2010s. In this context, preventing the progression of water in the streets or houses is a daily task, at least during the few months of the rainy season. Sitting in front 


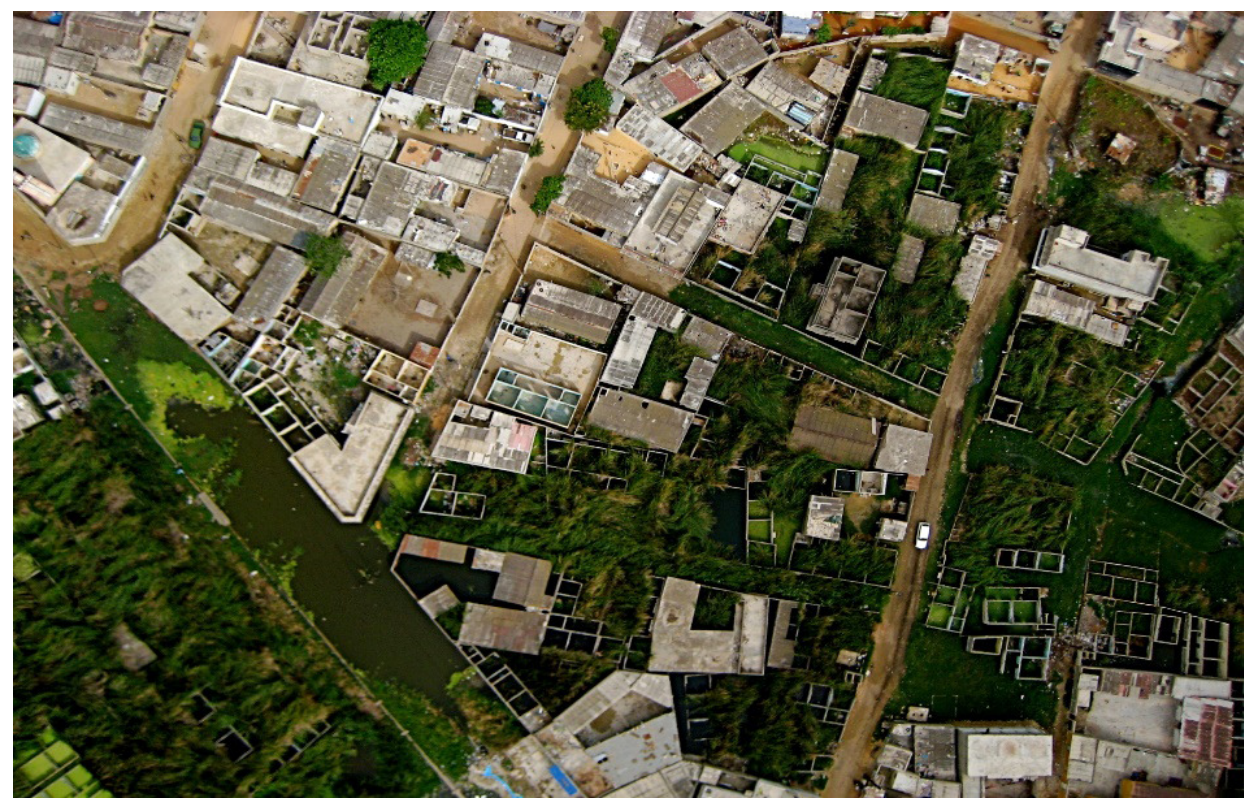

Figure 1. Abandoned neighbourhood in Medina Gounass. Source: Piriou (2019, p. 16).

of his house in the Leona neighbourhood, Mouhamadou Bathily (40s, unknown occupation, ex-member of local and municipal flood mitigation groups) explains that he has filled in his yard with sand several times and that he has moved the door of his house because of the advancing waters in his neighbourhood. Pointing to elec- tric poles protruding from the aquatic plants (typhas) in the abandoned neighbouring district, he describes the progressive advance, year after year, of the waters:

Romain: And you realised this from the start? That, as time went by, the level of water increased?

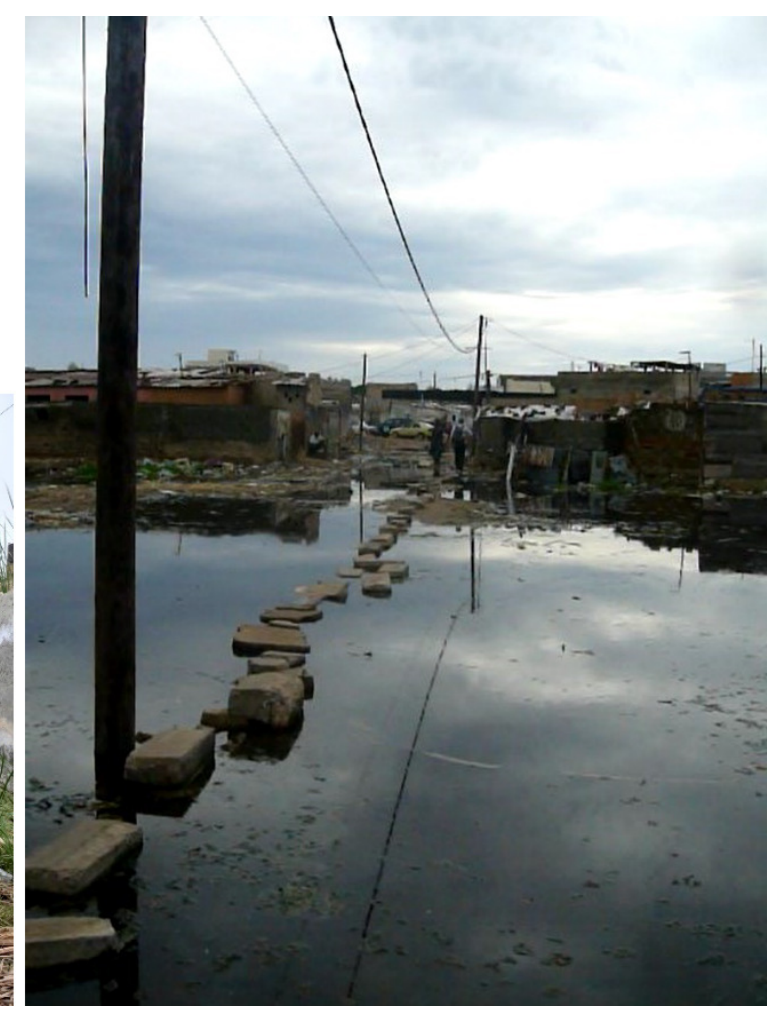

Figure 2. Leona (left) and Messere (right) today. Note: Entire sections of the city are now covered by water and typhas. Only the abandoned houses and businesses on the edge of the niaye (former wetlands) and the electric poles that sometimes emerge from the vegetation allow us to grasp the presence of old neighbourhoods in these areas. Source: Courtesy of Alex Amiguet and Djibril Diallo (pictures taken in 2011). 
Mouhamadou: It was increasing! Yes, it was increasing, at the time it was over there [he shows me a point far away, in the heart of the abandoned neighbourhood], the third pole. That's it. Since ' 92 , at that time the water reached the third pole there...... In 2009, the water was coming up to there, up to the first pole there [he shows me a power pole located right next to his house, and above the level of his yard, where he built his second door].

Then, showing me one of the houses, abandoned and invaded by typhas, located on the other side of the street, he explains:

The people who used to live in that house, now they are gone, but at that time, they were the last ones to stay. When they left, they broke the walls, the rooms that are there (the inhabitants wanted to recover some of the bricks from their house before leaving). So, they wanted to break this wall too [he shows me the outside wall of the house, which separates it from the street], but I was the one who said "no, you can't break that wall, because if you break that wall, the water will flood the street!" Yeah, at the time the street wasn't like that [today the street has been backfilled, clearly separating the abandoned area from the rest of the neighbourhood] but after 2009, those people left. Well after that it became like that. (Excerpt of the interview recorded on $26 / 08 / 2016$, in the street alongside his house in Leona, DTK)

The case of Mouhamadou is not isolated. In fact, in all areas regularly flooded or totally underwater, residents have been forced to fight against the inexorably advancing water for over two decades. This fight takes several forms, according to different behaviours of water. First, it could be a temporary departure or a collective mobilisation to evacuate the water from the houses and the yards using different containers. In this case, the mobilisation responds to the "intrusion" of the water and aims to deal with its brutal advance. However, as Mouhamadou explains, floods are also a creeping phenomenon of spatial-temporal expansion. As the year-round settlement of the water leads to the permanent abandonment of entire districts, it allows water to progress house by house and threaten more and more neighbourhoods. The fight against water is then carried out through the redirection of water (drainage, pumping) and containment. By preserving the walls of the old, abandoned houses and clearly separating the abandoned neighbourhoods from the others that are only slightly affected, it is a matter of slowing down the progression of the water as much as possible or even containing it within a limited perimeter. For the inhabitants that have abandoned their houses, or live near these areas, the water also acts in a third way: by stagnating. In these situations, the abandoned neighbourhoods are physically transformed and take on negative perceptions, becoming dangerous spaces for children (risk of drowning and diseases) and supposedly home to wild animals and bandits. For neighbours of these spaces or inhabitants of districts that are only temporarily under a regime of stagnant waters, soils are humid and the water is rising by capillary action in the cement walls and through the leaky septic tanks, gradually weakening the foundations and forcing a constant reinforcement work and raising of walls.

Water is acting, therefore, by permanent occupation and disintegration of the built environment. In DTK, the continuous action of waters has transformed the material and social structure of the city since the end of the 1980s, taking different forms, from the intrusion of water to stagnation within districts. These transformations are not, however, a one-way street. Efforts to manage and move water in the suburbs, embodied for example in large drainage infrastructure projects led by the state and the World Bank over the last 10 years, have notably drained certain areas that were previously underwater. These areas can now be repopulated and rebuilt, sometimes by their former owners, sometimes by newcomers. The struggle with water is not disappearing but moving to other places through ongoing negotiations between people and elements affected and affecting the urban environment. The form of this negotiation and the agency attributed to the matter depend on the scale of action, its objective, the actors involved, and the local configuration.

\section{Containing or Orienting the Waters? Two Specific Agencements at the Neighbourhood Scale}

In DTK, the municipality where I led inquiries, there are thus numerous ways to deal with several behaviours of waters in time of permanent floods (O. Cissé \& Sèye, 2015). It appears that both "ways to deal with floods" and "waters' behaviours" are not separate from one another but closely related. In DTK, to build walls or backfill houses to contain the progression of water as emphasised above and to drain or pump the water away from a flooded neighbourhood are two sets of activities related to different situations, diagnoses, and behaviours of water.

Backfilling houses or raising walls is relevant for individuals who live on the outskirts of flooded neighbourhoods-expected to be affected if nothing is done-or in temporary flooded neighbourhoods. "Temporary" refers here to an individual projection in the future, an expectation of households realised vis-à-vis the behaviours of waters and the degree of their "spatialtemporal" expansion (Will they extend up to my house? How long will they stay?) and current urban and social situation. DTK is indeed an old settlement of the suburbs of Dakar, considered as largely informal, originally populated with a mix of newcomers from the countryside and displaced people from Dakar during the eviction programs of the 1960s and 1970s (Faye \& Thioub, 2003; Vernière, 1977). Today, this municipality is one 
of the densest of the whole city, central compared to more recent settlements of the suburbs, and populated by old owners and their sons and daughters who were born in the agglomeration (Duboz et al., 2011), living in large households and with less than $10 \%$ of the population declaring a regular wage job (Gulyani et al., 2014). Combined with the land price explosion that occurred at the beginning of the 2000s (List, 2017), it becomes very difficult for people affected or expecting to be affected by floods to envisage leaving their house. Indeed, it would mean abandoning a property for a rented house, which is difficult to foresee with irregular wages, or for a new one located far from the city centre and from the social ties that allow entire families to face the multiple uncertainties that constitute everyday life. In this context, to abandon a house is a last resort, considered only when neighbours have gone, and the money has been spent on multiple house refurbishments and temporary solutions to protect oneself from the floods. Backfill and elevation of walls are part of these kinds of refurbishments. It requires a considerable amount of materials-sand for the most part, sometimes dishes for the poorest-to elevate parts or the totality of the house. This manner of dealing with the expansion of water does not consist in moving water, but other materials from different places to the backfill site, sometimes from a beach, far from DTK, sometimes from a close construction site, and sometimes from a more or less abandoned neighbouring area. It also requires the house owner to mobilise many people, diggers, sellers, transporters, and masons, depending on how wealthy they are, their degree of competencies, and the equipment necessary to carry out the different implied operations. This mobilisation of heterogeneous elements, of different anticipations of the situation, and of the behaviours of these elements, oriented toward a strategic goal that could be summarised in scientific words like "staying in this house despite the spatial-temporal expansion of waters and given the current urban and housing situation," could be considered as an agencement, corresponding to this specific situation.

The pumping of water or digging of drainage channels correspond to another agencement, more related to collective spaces and the stagnation of water. When districts, streets, or street corners are permanently underwater during a long period but still not totally abandoned by people, or highly important for urban and social functions like a main road or a mosque corner, it could lead to the formation of a collective organised around the pumping of one or more of those sites. Schaer and Hanonou (2017) described this kind of situation in Guinaw Rail, another municipality of the Dakar suburbs, where residents, local organisations, firemen, public authorities, brokers, and sectorial services are gathered to "co-produce flood response services." I also showed in a previous article (Leclercq, 2019) how this kind of collective needs to defend and justify a "common worth," adapted to a "correct" diagnosis of the situation and thus to a "correct" objective, to legitimate its intervention. Here, what is interesting is that these objectives and diagnoses depend on each other and the behaviour of waters. Like a member of a local organisation said, these collective actions are not legitimate because they are effective, but because they are considered by the affected people, the firemen, and the local organisations as an adapted solution, at least a possible one, considering the stagnation of water:

Pape Gueye: There was also a captain of the fire brigade who lives here, his name was Abdoulaye Ndiaye. He was the commander of the fire brigade which is here. Once they gave us 17 tankers.

Romain: To pump water?

Pape Gueye: To pump water. But it was reluctantly. They pumped for maybe 10 days. But on the 10th day, we found that not a single litre of water was gone.

Romain: It didn't change anything?

Pape Gueye: It changed nothing, nothing. It was at Daroulaye [name of a district], you know, it's always flooded there....Even him [the captain of the fire brigade], two years after that, he told me that he knew that it was not going to do anything, but he had to do something to reassure people.....Even we [his local organisation] sometimes had strategies. Sometimes, people were exhausted by the water, when we arrived with a motor-pump they were... they could even sleep in the water. Because they will see, they will know that "this water will go because there's the machine." Sometimes, we didn't even pump, but we put it in. (Excerpt of the interview with Pape Gueye, 40s, mechanic, member of a municipal flood mitigation group. Interview recorded on 16/08/2016 in an office of the DTK town hall)

The stagnation of water, here characterised by the "always flooded district" situation, makes the pumping ineffective in certain cases. In many more or less permanently flooded areas, it is the high level of the groundwater table that causes the water to stagnate, but, because individual backfilling would be impossible in time and space of stagnation, pumping appears as the most adapted solution considering the means of people and their understanding of the situation. If the water has established here, it is better to "make the water go," organising its circulation through pumps and rubber pipes from the flooded zone to tankers, or, more commonly, to another flooded zone. Working at the very core of waters as well as in close contact with affected people, actors like Pape Gueye are trying to "reassure people" in absence of a good solution to address the stagnation of water, creating and maintaining with other actors like firemen a "co-produced flood response service" 
agencement. The general objective targeted by those actors, in an attempt to maintain both the networks that allow water to circulate (pumps, tankers, rubber pipes and those who care) and people to be reassured through ongoing negotiations, is the "relief of the community" (Leclercq, 2019) and not the protection of one house or another. In doing so, they are participating in an intricate process of social and physical change of the city itself.

Indeed, these two different agencements are participating in the dynamic of transformation of the city through the floods. Considering the first, consisting of backfilling houses and raising walls, it could be very detrimental for the neighbours that one household alone starts to move sand from elsewhere to their home to keep water out. Indeed, these operations guide the circulation of water in neighbourhoods, possibly toward someone else's house, thus creating what actors called a "low point" ("point bas" in French), an area that collects water from the neighbourhood because of its topography. This process could be amplified if the "back filler" collects sand directly from the road of another neighbourhood. These areas usually become stagnation areas for water, leaving no other solution for people living there but to pump if they can gather enough actors, resources, and materials. If they cannot, they would have to leave the house temporarily, hoping that the water will be gone one day, allowing, in turn, to backfill the house or to leave it permanently if the problem persists. Pumping raises the same kind of problem. When you start to pump somewhere, you have to bring the water elsewhere. But, in the crowded districts of DTK and due to the absence of tankers, it usually means that you will bring it to other neighbourhoods, partially or totally flooded, creating conflicts with people living on the outskirts, as well as on the layout of the pipes.

The scale, status, and expected behaviours of the elements and people involved in these agencements, as well as the targeted goals or common worth, become here the very question of understanding what differentiates these two kinds of agencement. If the urban consequences and the general process of negotiation between people and water could be the same in both cases, i.e., trying to assess the behaviours of the latter to adopt a solution that is as adapted as possible in a specific urban and social context, the common worth, the objectives, and the actors involved are not. In a backfilling agencement, the worth is clearly related to self-protection, targeted individual households against a problem that is perceived to be manageable at the house scale. In a coproduced flood response service agencement, the worth is collective, targeting a community problem, and involving representative actors or actors that are legitimately doing something for the community. Still, degrees and diversity exist in these different agencements, but their forms appear to be relatively stable at this scale, considering that we can recognise both approaches to dealing with water in different municipalities of the Dakar suburbs (O. Cissé \& Sèye, 2015; Schaer \& Hanonou, 2017).

\section{From One Agencement to Another: How to Reach the Right Scale and Stay There}

As many authors have shown, the scale of an agencement depends on the tools and actors implied, their networks, the arenas that they reach, and the common worth that they claim (Boltanski \& Thévenot, 2006; Latour, 2005; Müller \& Schurr, 2016). To understand how the behaviours of waters could be enrolled in an agencement at the city scale, but also how it can be relegated to a secondary question through the shift of one agencement to another, allowed for the observation of the trajectory of one DTK organisation and a Swiss NGO that had an important impact on the flood treatment in Dakar.

\subsection{Debating Causes and Consequences of Floods at the City Scale: The Emergence of an Urban Forum}

From 2005 onwards, the year of a major flooding episode, demonstrations and marches questioning local authorities in the Dakar suburbs increased. These demonstrations had two major demands. The first was an appeal to the state to provide "permanent" solutions to a problem that had already lasted for more than 15 years at the time of the events, without any largescale solutions (B. Cissé et al., 2018; Leclercq, 2020). The second is the proclaimed right to inhabit for so-called "informal dwellers," threatened by both water and urban policies to "clear" informal settlements. Indeed, as 30\% of the Dakar suburbs, most of the DTK municipality is inhabited by owners without formal property rights, allowing the state to easily displace them and take their land in case of permanent flooding for instance (Leclercq, 2017; List, 2017). In this context, a group of local organisations of DTK started to explore the floods problem with a Swiss NGO in 2007, diagnosing it and searching for structural solutions. This resulted in a development project, conducted between 2010 and 2013 and financed by Swiss donors, building a participatory urban plan for the slum upgrading of the municipality of DTK.

By modelling the dynamics of the water table under DTK and by comparing these models to the rainfall records of the region and World Bank documents on water management in the capital, they realised that the forms of stagnation and progression of water were mainly the result of the gradual rise of the water table located under the suburbs. The latter, fed by both rainwater and wastewater from the populations settling in the urban peripheries of the Senegalese capital throughout the 20th century, has indeed experienced a considerable net inflow of water from the 1990s, combined with the cessation of its use to supply Dakar with drinking water in the early 2000s (B. Cissé et al., 2018; Leclercq, 2017). As a result, the group of organisations and the NGO proposed to resume pumping the water table to lower its level, redirecting the collected water to farmers on the outskirts of the agglomeration, and to take advantage of the spaces thus regained from the water to install sanitation 
and drainage infrastructure, and to relocate the populations affected by the floods. This program was carried out first on the scale of the water table, then on the scale of the municipality in an attempt to integrate hydrogeological entities (the water table) and the dwellers' claims (to remain living in their neighbourhoods). To do so, they organised survey and urban planning groups in the whole city, divided into three zones, and they used specific tools, maps, surveys (Figure 3), and World Bank reports to target specific actors and spaces, not only those affected by floods, but mainly decision-makers at the city and national level. They claimed for a kind of urban development, the slum upgrading, widely valued by international institutions since the 1980s (Deboulet, 2016; Huchzermeyer, 2014) and presented since the late 1990 s by Senegalese newspapers as a possible solution to informal urbanisation (Leclercq, 2020). Enrolling local organisations, the municipality of DTK, and the regional council, producing debates about causes and consequences of floods (Thoenig, 1998), and finally reaching state agencies, ministries, and even the president of the republic a few months before elections, they called for "commensurate" flood responses (Boltanski \& Thévenot, 2006; Khan, 2019). The form of this emerging agencement is close to a "forum" (Callon et al., 2009), gathering different actors, more or less representative, to produce a collective decision about the floods comprised as a public problem with debatable causes and behaviours. It assumed that the city and the state as a set of sociopolitical institutions would be able to conduct the resulting major urban policy, which they did in part, integrating the resuming of pumping and some of the insights of the project to the Decennial Plan for Flood Management declared in 2012 by the President of the Republic Macky Sall (Bottazzi et al., 2019). The silent adoption of some of these proposals, the end of the project in 2013 and of

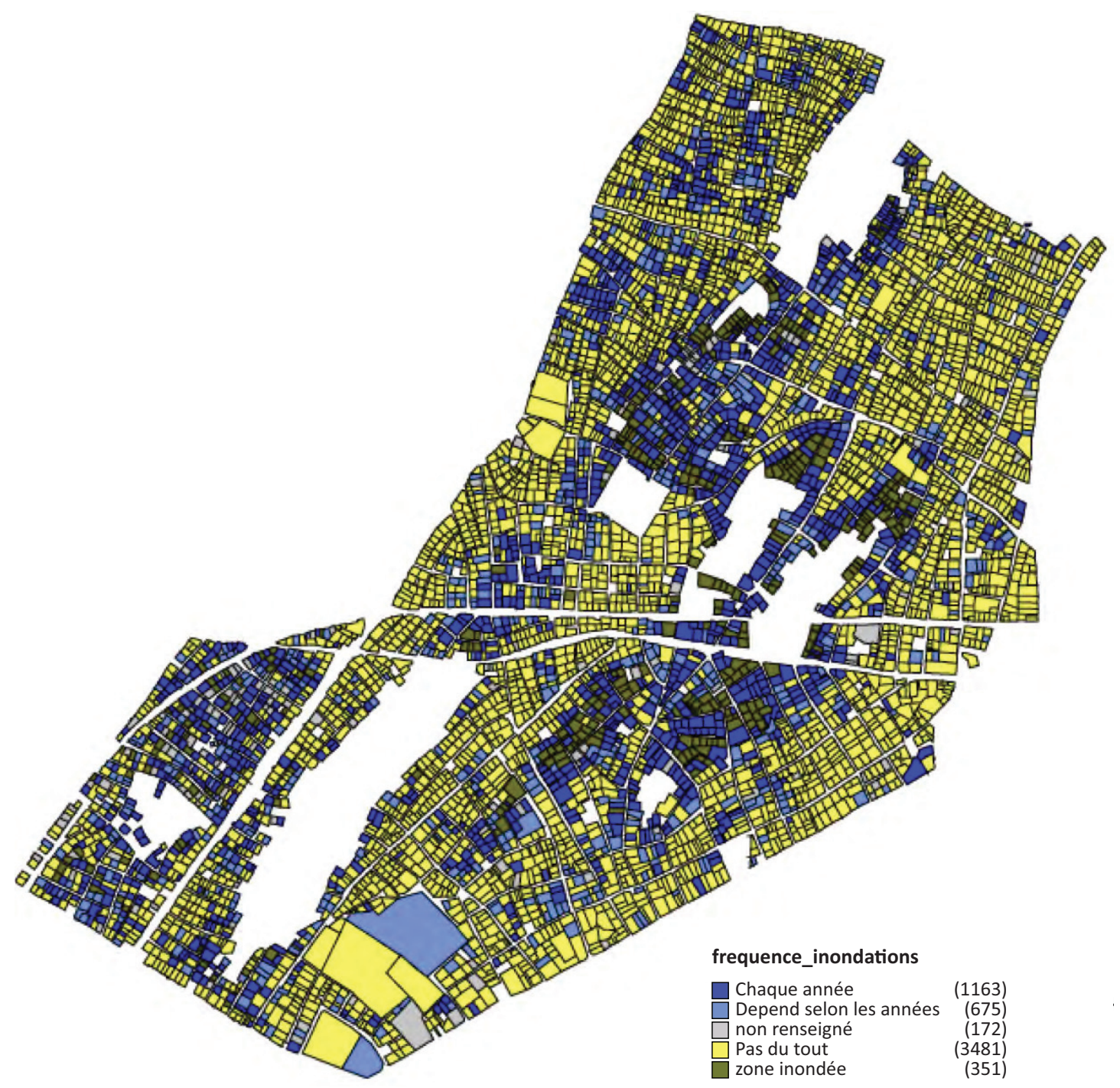

Figure 3. Mapping the action of the water. Note: This map, produced by DTK's community organisations and a Swiss NGO, is based on a plot-by-plot survey aiming to identify, among other aspects, the frequency of floods for each house of the city. The darker the colour, the more water stagnates there during the year. Caption (from the dark blue square to the green one): "Each year; depending on the years; data not provided; not at all; flooded zone." Source: Keita et al. (2012, p. 38). 
the associated support to DTK's local organisations, the fall of the Regional Council of Dakar the same year due to a new decentralisation act, and the change of majority at the DTK municipality in 2014 led to the end of this agencement. The DTK organisations and the Swiss NGO shifted, from 2014, to another format of action.

\subsection{Shifting From a Forum to a Platform: How Do Agencements Orient the Production of the City?}

At the end of this first project, the DTK organisation groups and the Swiss NGO had to find new funding while the continuation of its action program, the urban upgrading of the commune of DTK, and the pumping of the water table was handed over to the political authorities. Indeed, pursuing this kind of project at this scale demands a huge amount of money, which only international donors can provide in Senegal. In addition, intraorganisational conflicts among the people of the DTK group and around the management of funding led to a scission. The ex-president of the group joined the Senegalese consultants and volunteers that were part of the first project to create a new NGO, allied with the Swiss one, and were able to receive funds from international donors. In 2014, members of the Swiss NGO met with representatives of a network of NGOs and federations of slum dwellers at the World Urban Forum in Medellín, Colombia. Joining this network, the new Senegalese NGO and the Swiss NGO began to transform their mode of action as well as their target.

This new way of functioning was based on the travelling model (Behrends et al., 2014) developed by the international network of NGOs, and consisting in the use of community finance (Mitlin et al., 2018) to lead urban projects for and by the so-called slum communities. According to this model, an urban project should be financed in part by the money of the dwelling people through a community savings group system. Indeed, for its promoters, community savings allow inhabitants of the same place to gather around something, to exchange about the problems of their community, and to improve confidence between them. On this basis, it becomes possible to identify solutions to community problems, to start to finance those solutions with savings, or to implement partnerships with public or private institutions or donors. In each of these partnerships, which usually take the form of a project, the savings group, supported by their NGO, should lead the project, assuming that they are best suited to know what projects should be implemented in their community. Also, if a certain level of subvention is possible, no project should be executed for free, assuming that community finance improves the ownership of projects, that is to say, that each project should be totally or partially reimbursed by whoever benefits from it. The whole point of this model thus consists in providing the slum dwellers, organised in savings groups, and technically helped by a supporting NGO, with the means to conceive and implement urban poli- cies that target their communities, as well as to lead negotiations with actors that could finance and implement these policies.

The goal here is not to evaluate this model or its primary assumptions but to see how its implementation transformed the action of the Swiss and the Senegalese NGOs. In 2015, they built a third structure federating different informal saving groups in Dakar suburbs and other cities of the country. Trying to adapt the model to the flooding problem, they started to implement a credit system which would allow the rebuilding of floodingaffected homes. Through Swiss funding, the NGOs built a federation's fund dedicated to this project, which was used to finance the reconstruction of a room destroyed or abandoned by flooding, the backfill of a courtyard, or the raising of walls. The beneficiaries of these loans then had to reimburse through their savings group. However, the credit was not the only difficulty. The NGO also had to be sure that the loans were dedicated to a viable construction project. Thus, they engaged construction engineers to define the work that could be done with the loan beneficiary, to control the quotes, and to train masons. In addition, they refined their data collection techniques through the use of drones, digital questionnaires, and engaging the savings groups and their communities into cartography and the surveying of more and more municipalities. After a difficult start, the number of individual rebuilding or rehabilitation projects increased in DTK. Between 2016 and 2018, more than 200 houses were aided by the Senegalese Federation and its supporting NGO, and 400 more between 2018 and 2021, with the organisation growing and attracting more and more donors and international organisations.

If the project and the structures still running today are considered as a success story (Behrends et al., 2014), the agencement is no longer the same. Integrating a new network and trying to model themselves as durable holders of international funds, the Senegalese NGO and the savings groups are now concerned with the effects of the floods on individual households and not with the behaviours of waters and their consequences at the scale of municipalities. Their objectives are now more centred on housing for the poor than on floods, relegated as a justification for their action. Their structure aims to channel international or local funds toward individual constructions, assuring the payback and the effectiveness of the service.

Currently, the data collection can integrate demands from other organisations, such as municipalities or international organisations, concerning different topics like sanitation, education, etc. The negotiations are now taking the form of partnerships, not open discussions, around projects and not around the government of the city as a whole. In fact, the collective decision of a political community is no longer a question through this agencement, but the sharing of resources attracted and distributed according to defined formats and processes between the different participants (Urfalino, 
2020). The form of the city held by this agencement is no longer the same: It went from a planned city, collectively shaped by representatives trying to seize and control the different entities that composed it, to an aggregation of households, shaped by the networks allowing individuals to act on their own and to fight against an untamed environment. This last agencement points towards a platform structure, qualifying, targeting, and articulating "needs" of "slum dwellers" and "concerns" of "service providers" (Callon, 2017). Analysing how these specific structures are shaping landscapes (Berglund, 2019; Tsing et al., 2019) and orienting the production, maintenance, or disintegration of cities as social and material organisations appears to be an important task for urban studies.

\section{Conclusion}

In this article, I attempted to distinguish three "behaviours" by which waters are fluidifying Dakar's suburbs through floods. The first is that of "intrusion," when waters brutally intrude into the daily lives of inhabitants, carrying filthy matter, damaging, or destroying goods, even inside homes. The second is that of "spatialtemporal expansion," when water advances force the inhabitants to resist this expansion or to leave when money or strength runs out. The third is that of "stagnation," when the water, because it has established for too long or because the water table is too high, rises through the floors and walls, becoming part of the very structure of the houses and participating in their slow disintegration.

We saw different forms of collective action pairing to two of these behaviours, at the scale of houses and neighbourhoods. Together, they formed specific agencements, articulating water, sands, and motor-pumps to dwellers, transporters, and one of them to public authorities, local organisations, and sectoral services. I called the first one, for want of a better term, "backfilling agencement." Oriented toward the containment of water outside one's house, it allows individuals and households to protect themselves from floods but can also have detrimental consequences on neighbours, reorienting the dynamic of waters and modifying, from one house to another, the topography of the city itself. Obviously, it favours wealthier households that have enough money to elevate their houses, but it also takes place in a situation where house ownership is often a major pole of stability for people that benefit from irregular wages in a context of land-price explosion, allowing the maintenance of social ties and ensuring housing. This explains the huge amount of money spent annually, even by poor households, to protect their house and to stay in their neighbourhood even if it means being underwater during a part of the year (A. Cissé \& Mendy, 2018). The second one is a co-produced flood response service. I took the example of motor-pumping of stagnant water to emphasise the negotiated character of public service here as well as the sometimes-inefficient charac- ter of the pairing with water behaviours. Indeed, targeting the "relief of community," this agencement is built through inter-individual negotiations with local institutions representatives, often unable to act through commensurate means at the scale of the entities involved, here the groundwater table. This kind of agencement had been well described for a long time by researchers interested in governance and public service delivery in Africa (Bierschenk \& Olivier de Sardan, 2014; Blundo \& Le Meur, 2009), and had proven its effectiveness for different services in contexts characterised by scarce resources and the multiplicity of actors involved in their deliverance (Schaer \& Hanonou, 2017), but it is important to note that entities implied here are simply too big to be grasped by this form of collective action.

This last agencement raised a scale question. I tried to explore this question by observing the evolution of the collective action of a local organisation group and an NGO both engaged in an exploration of the dynamics of the floods at the DTK scale. Gathering experts, DTK dwellers, and decision-makers to collectively explore a problem in what I called an urban forum agencement (close to an "hybrid forum", see Callon et al., 2009), they tried to reach a solution at the city and the groundwater scales. But after a few years, this agencement shifted toward a new one which we can call an "international slum service platform," linking and modelling international and national offer to local demand in precarious neighbourhoods through ongoing negotiations and partnerships between service providers and "poor urban communities." During this process, the place of floods and water behaviours changed. From the central object of the collective action of these organisations, they became a secondary one, justifying a housing-oriented agencement. When we are looking at the trajectories of the actors involved, this shift is full of contingencies and choices in a set of constraints and possibilities, but looking at the shifting form of the agencements itself and the trajectories of organisations involved, from communitybased organisation to NGO, from NGO to member of an international network, and from a forum to a platform, we start to see common patterns that are reminiscent of the trajectory of similar organisations in different contexts (Eliasoph, 2011; Stockwell \& Dimier, 2020; Talpin, 2020). Again, these agencements are not even regarding their goal and the form of action that they support. Indeed, they are individuals, community or society focussed, specifics or generalists, "problems" solving or "needs" oriented. From these intermediate objects, always precarious at their scale but relatively stable as a form, it becomes possible to link capital-oriented infrastructures, particular sets of constraints, concepts or models that allow some agencements and discourage others, that support specific kinds of actions, and assemblages oriented toward and through the urbanisation process. It also becomes possible to analyse the unexpected consequences of the interactions between these different agencements and flux in specific urban settings (Naepels, 
2018). Trying to name and understand these intermediate forms that orient how cities are produced, maintained, or disintegrated appears to be a step toward an understanding of cities as unstable, evolutive, and precarious milieus.

\section{Conflict of Interests}

The author declares no conflict of interests.

\section{References}

Behrends, A., Park, S. J., \& Rottenburg, R. (2014). Travelling models. Introducing an analytical concept to globalisation studies. In A. Behrends, S. J. Park, \& R. Rottenburg (Eds.), Travelling models in African conflict management: Translating technologies of social ordering (pp. 1-40). Brill.

Berglund, E. (2019). Troubled landscapes of change: Limits and natures in grassroots urbanism. In E. Berglund, A. Lounela, \& T. Kallinen (Eds.), Dwelling in political landscapes. Contemporary anthropological perspectives (pp. 196-212). SKS.

Bierschenk, T., \& Olivier de Sardan, J.-P. (2014). States at work. Dynamics of African bureaucracies. Brill.

Blundo, G., \& Le Meur, Y. P. (2009). The governance of daily life in Africa: Ethnographic explorations of public and collective services. Brill.

Boltanski, L., \& Thévenot, L. (2006). On justification: Economies of worth. Princeton University Press.

Bottazzi, P., Winkler, M., \& Speranza, C. (2019). Flood governance for resilience in cities: The historical policy transformations in Dakar's suburbs. Environmental Science and Policy, 93, 172-180.

Brenner, N., Madden, D. J., \& Wachsmuth, D. (2011). Assemblage urbanism and the challenges of critical urban theory. City, 15, 225-240.

Callon, M. (2017). L'emprise des marchés. Comprendre leur fonctionnement pour pouvoir les changer [The grasp of markets. Understanding how they work to be able to change them]. La Découverte.

Callon, M., Lascoumes, P., \& Barthe, Y. (2009). Acting in an uncertain world: An essay on technical democracy. MIT Press.

Cefaï, D. (Ed.). (2010). L'engagement ethnographique [The ethnographic commitment]. Éditions de l'EHESS.

Choplin, A. (2019). Cementing Africa: Cement flows and city-making along the West African corridor (Accra, Lomé, Cotonou, Lagos). Urban Studies, 57(9), 1977-1993. https://doi.org/10.1177/00420980198 51949

Choplin, A. (in press). Concrete city, cement and urban fabric in West Africa. Wiley.

Cissé, A., \& Mendy, P. (2018). Spatial relationship between floods and poverty: The case of region of Dakar. Theoretical Economics Letters, 8, 256-281.

Cissé, B., Quensière, J., \& Kane, A. (2018). Vulnérabilisation ou résilience des banlieues insalubres de Dakar
[Vulnerability or resilience of the unhealthy suburbs of Dakar]. Mondes en Développement, 181(1), 131-146. https://doi.org/10.3917/med.181.0131

Cissé, O. (Ed.). (2019). Les inondations à Dakar. Gestion des risques et adaptations locales [Flooding in Dakar. Risk management and local adaptation]. IAGU.

Cissé, O., \& Sèye, M. (2015). Flooding in the suburbs of Dakar: Impacts on the assets and adaptation strategies of households or communities. Environment and Urbanization, 28(1), 183-204.

Deboulet, A. (Ed.). (2016). Repenser les quartiers précaires [Rethinking precarious neighbourhoods]. Agence Française de Développement.

Deleuze, G., \& Guattari, F. (1975). Kafka. Pour une littérature mineure [Kafka. For a minor literature]. Éditions de Minuit.

Dodier, N., \& Stavrianakis, A. (Eds.). (2018). Les objets composés. Agencements, dispositifs, assemblages [Composed objects. Agencements, devices, assemblages]. Éditions de l'EHESS.

Duboz, P., Macia, E., Gueye, L., Boëtsch, G., \& ChapuisLucciani, N. (2011). Migrations internes au Sénégal. Caractéristiques socioéconomiques, démographiques et migratoires des Dakarois [Internal migrations in Senegal. Socioeconomic, demographic, and migratory characteristics of Dakar dwellers]. Diversité Urbaine, 11(2), 113-135.

Eliasoph, N. (2011). Making volunteers. Civic life after welfare's end. Princeton University Press.

Faye, O., \& Thioub, I. (2003). Les marginaux et l'État à Dakar [Marginals and the state in Dakar]. Le Mouvement Social, 3(204), 93-108.

Gulyani, S., Bassett, E., \& Talukdar, D. (2014). A tale of two cities: A multi-dimensional portrait of poverty and living conditions in the slums of Dakar and Nairobi. Habitat International, 43, 98-107.

Huchzermeyer, M. (2014). Troubling continuities. Use and utility of the term "slum." In S. Parnell \& S. Oldfield (Eds.), The Routledge handbook on cities of the Global South (pp. 86-97). Routledge.

Keita, P. A., Mbaye, R., Skrzypec, A., Charpentier, C., Diallo, D., Dieng, M., Bâ, Y., Cissé, C. T., \& Coly, M. (2012). Restructuration et régularisation foncière de Djiddah Thiaroye Kao. Synthèse de la planification participative [Urban restructuration and regularisation of Djiddah Thiaroye Kao. Participative plan synthesis]. UrbaDTK. https://inondations-dakar.org/ en_GB/dataset/synthese-de-la-planificationparticipative-2012-djiddah-thiaroye-kao-urbadtk

Khan, N. (2019). At play with the giants. Between the patchy Anthropocene and romantic geology. Current Anthropology, 60(Suppl. 20), 333-341.

Latour, B. (2005). Reassembling the social: An introduction to actor-network theory. Oxford University Press.

Leclercq, R. (2017). The politics of risk policies in Dakar, Senegal. International Journal of Disaster Risk Reduction, 26, 93-100. 
Leclercq, R. (2019). L'action publique à l'épreuve des inondations dans la banlieue de Dakar [Flood-proof public action in the suburbs of Dakar]. Anthropologie \& Développement, 50, 31-50.

Leclercq, R. (2020). Dakar, proie des eaux. Sociologie de la ville catastrophée [Dakar, prey of waters. Sociology of the catastrophized city] [Doctoral dissertation, Université Paris 8]. Inondations-Dakar. https://inondations-dakar.org/dataset/dakar-proiedes-eaux-sociologie-de-la-ville-catastrophee

List, N. (2017). Land grabs in urban frontiers: Producing inequality in Senegal's Dakar region [Doctoral dissertation, University of California, Berkeley]. eScholarship. https://escholarship.org/uc/item/5h4681nd

Marcus, G. E. (1995). Ethnography in/of the world system: The emergence of multi-sited ethnography. Annual Review of Anthropology, 24, 95-117.

McFarlane, C. (2011). Learning the city: Knowledge and translocal assemblage. Wiley.

McGuirk, P.-M., Mee, K. J., \& Ruming, K. J. (2016). Assembling urban regeneration? Geography Compass, 10(3), 128-141.

Meulemans, G. (2020). Urban pedogeneses. The making of city soils from hard surfacing to the urban soil sciences. Environmental Humanities, 12(1), 250-266.

Mitlin, D., Colenbrander, S., \& Satterthwaite, D. (2018). Finance for community-led local, city and national development. Environment and Urbanization, 30(1), 3-14.

Müller, M., \& Schurr, C. (2016). Assemblage thinking and actor-network theory: Conjunctions, disjunctions, cross-fertilisations. Transactions of the Institute of British Geographers, 41(3), 217-229.

Naepels, M. (2018). L'aide humanitaire à Pweto. Un assemblage incertain de personnes et de ressources [Humanitarian aid in Pweto. An uncertain assemblage of people and resources]. In N. Dodier \& A. Stavrianakis (Eds.), Les objets composés. Agencements, dispositifs, assemblages [Composed objects. Agencements, devices, assemblages] (pp. 303-327). Éditions de l'EHESS.

Piriou, G. (2019). Terre-typha. Emergence d'une autre manière de construire au Sénégal [Earth and typha. The emergence of another way to build in Senegal] [Master's thesis, School of Architecture of Nantes]. HAL. https://hal-univ-tlse3.archives-ouvertes.fr/ MEM-ENSA-44/dumas-03132373

Rose, M. (2012). Dwelling as marking and claiming. Environment and Planning D: Society and Space, 30(5),
757-771.

Schaer, C., \& Hanonou, E. K. (2017). The real governance of disaster risk management in peri-urban Senegal: Delivering flood response services through coproduction. Progress in Development Studies, 17(1), 38-53.

Scott, A. J., \& Storper, M. (2015). The nature of cities: The scope and limits of urban theory. International Journal of Urban Theory, 39, 1-15.

Simone, A. (2010). City life from Jakarta to Dakar: Movements at the crossroads. Routledge.

Stockwell, S., \& Dimier, V. (2020). The business of development in post-colonial Africa. Palgrave MacMillan.

Talpin, J. (2020). La force du nombre: Un impératif managérial? Le community organizing travaillé par le tournant néolibéral [The power of numbers: A managerial imperative? Community organizing and the neoliberal turn]. In M. Juan (Ed.), Du social business à l'économie solidaire: Critique de l'innovation sociale [From social business to solidarity economy: Critique of social innovation] (pp. 139-158). Érès.

Tedlock, B. (1991). From participant observation to the observation of participation: The emergence of narrative ethnography. Journal of Anthropological Research, 47(1), 69-94.

Thiam, M. D. (2011). Le syndrome des inondations au Sénégal [The flooding syndrome in Senegal]. Presses Universitaires du Sahel.

Thoenig, J.-C. (1998). L'usage analytique du concept de régulation [The analytical use of the concept of regulation]. In J. Commaille \& B. Jobert (Eds.), Les métamorphoses de la régulation politique [Metamorphoses of political regulation] (pp. 35-53). LGDJ.

Tsing, A., Mathew, A., \& Bubandt, N. (2019). Patchy Anthropocene: Landscape structure, multispecies history, and the retooling of anthropology. Current Anthropology, 60(Suppl. 20), 186-197.

Urfalino, P. (2020). Décider ensemble. La fabrique de l'obligation collective [Deciding together. The making of collective obligation]. Seuil.

Vernière, M. (1977). Volontarisme d'Etat et spontanéisme populaire dans l'urbanisation du TiersMonde. Formation et évolution des banlieues dakaroises: Le cas de Dagoudane Pikine [State voluntarism and popular spontaneity in Third-World urbanisation. Formation and evolution of Dakar suburbs: The case of Dagoudane Pikine]. Bibliothèque Nationale de France.

\section{About the Author}

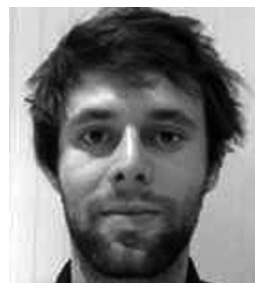

Romain Leclercq is a sociologist and an urbanist, postdoctoral fellow at the Earth Politics Center (University of Paris and Sciences Po). After defending his doctoral thesis at University Paris 8 and the LAVUE laboratory (UMR 7218), he is currently working on urban disasters in the Anthropocene in an ethnographic and comparative perspective. His main research fields are situated in Dakar (Senegal), Accra (Ghana), and Saint-Denis (France). 